\title{
Traditional and alternative nonlinear models for estimating the growth of Morada Nova sheep ${ }^{1}$
}

\section{Laaina de Andrade Souza ${ }^{2}$, Paulo Luiz Souza Carneiro ${ }^{3,5}$, Carlos Henrique Mendes Malhado ${ }^{3}$, Fabyano Fonseca e Silva ${ }^{4}$, Fernanda Gomes da Silveira ${ }^{4}$}

\author{
${ }^{1}$ Study financially aided by Banco do Nordeste and Fapesb. \\ 2 Universidade Estadual do Sudoeste da Bahia - UESB/Itapetinga, BA, Brazil. \\ ${ }^{3}$ Universidade Estadual do Sudoeste da Bahia - UESB/Jequié, BA, Brazil. \\ ${ }^{4}$ Universidade Federal de Viçosa - UFV/Viçosa, MG, Brazil. \\ ${ }^{5}$ Researcher on Productivity, financially aided by CNPq.
}

\begin{abstract}
In the present study, alternative and traditional nonlinear models to describe growth curves of Morada Nova sheep reared in the state of Bahia, Brazil, were applied. The nonlinear models were: Schnute, Mitscherlich, Gompertz, Logistic, Meloun I Meloun II, III Meloun, Gamito and Meloun IV. The model adjustment was evaluated by using: Adjusted Coefficient of Determination $\left(\mathrm{R}^{2}\right.$ aj , Akaike Information Criterion (AIC), Bayesian Information Criterion (BIC), Mean Squared Error of Prediction (MEP) and Coefficient of Determination of Prediction $\left(\mathrm{R}_{\mathrm{p}}^{2}\right)$. The selection of the best model was based on cluster analysis, using the evaluators as variables. Six out of the nine tested models converged, while Meloun I and Meloun IV were equally effective in explaining animal growth, without significant influence of sex or type of parturition over the curve parameters. The models Meloun I and IV have the best adjustment and reveal a remarkable reduction of weight gain after 150 days of age, which indicates special attention should be given to feeding at this stage.
\end{abstract}

Key Words: cluster analysis, growth curve, naturalized breed

\section{Introduction}

In recent years, studies focusing on growth curves have increased due to the development of new computational techniques for faster and more accurate analyses as well as the availability of new models to be tested (Silveira et al., 2011). This approach is advantageous to animal production since it assures understanding the animal growth by including parameters of biological interpretation (Silva et al., 2004; Malhado et al., 2008; Silveira et al., 2011).

Several studies addressing growth curves have used Brody, Von Bertalanffy, Richards, Logistic and Gompertz nonlinear models (McManus et al., 2003; Freitas, 2005; Sarmento et al., 2006; Carneiro et al., 2007, 2009). On the other hand, alternative models such as Schnute, Mitscherlich, Meloun I Meloun II, Meloun III, Gamito and Meloun IV remain overlooked in animal science. For instance, Schnute, Meloun I and II and Mitscherlich models have been adopted by Meloun \& Militk (1996) to describe the growth of human fetuses and due to their great flexibility, these models are potentially useful to describe the growth curves in animals.

Morada Nova is an indigenous hair sheep breed from northeastern Brazil, characterized by its great adaptation to semi-arid conditions and high-quality meat and skin, highly appreciated in the international market. Because of its small size and adaptability, Morada Nova plays an important role to smallholders in rural areas (Domingues, 1941, 1950; Gurgel et al., 1992).

In spite of their importance to the human population in northeastern Brazil and potential for international trade, Morada Nova populations are dispersed into small flocks across different regions of Brazil and lack genetic monitoring. Regarding this situation, several research groups and funding agencies have invested in restoration and in-situ and ex-situ conservation of genetic variation in Morada Nova to be used in breeding programs (Facó et al., 2008).

Research studies based on nonlinear models to describe the growth of Morada Nova sheep are still scarce. After choosing the model that best fits the growth pattern, the descriptive parameters need to be evaluated to identify the factors that may influence growth, like breed, sex, birth type, season, year of birth and age of the mother at calving (Sarmento et al., 2006).

Therefore, this paper describes the best adjusted nonlinear models to weight and age in Morada Nova sheep based on different quality evaluators and cluster analysis. The influence of non-genetic factors on model parameters was also investigated. 


\section{Material and Methods}

Weight data from 40 Morada Nova sheep kept at Estação Experimental da Empresa Baiana de Desenvolvimento Agrícola S.A (Experimental Station of Agricultural Development of Bahia State SA - EBDA) were obtained at every two weeks from birth to 370 days of age. Weighing was initiated in October 2006 and concluded in November 2007, a period with rainfall of $1171 \mathrm{~mm}$. Lambs were weaned at 120 days of age and reared under extensive system, in pasture areas of Panicum maximum (30\%) and Brachiaria decumbens (70\%). Commercial mineral salt was provided to the animals ad libitum.

A total of nine nonlinear models were evaluated to describe the growth of sheep, two of which are routinely used in studies of animal growth (Gompertz and Logistic) and seven represent alternative models (Table 1).

In all models, parameter $\beta_{1}$ represents the adult or asymptotic weight of the animal, whereas parameter $\beta_{3}$ denotes the maturity rate or growth rate. Models showing parameter $\beta_{4}$ have a variable inflection point, whose location is determined by the parameter in question. In general, there is no practical interpretation for the parameter $\beta_{2}$, which is a constant of integration.

The quality evaluators of nonlinear models are detailed as follows.

Adjusted coefficient of determination $\left(\mathrm{R}_{\mathrm{aj}}^{2}\right)$ : used to compare the quality of model with different parameter numbers ( $p$ ). The formula is represented by:

$$
R^{2} a j=R^{2}-\left(\frac{p-1}{N-p}\right)\left(1-R^{2}\right)
$$

Table 1 - Nonlinear regression models to describe growth curves

\begin{tabular}{|c|c|}
\hline Model & Formula \\
\hline Logistic & $y_{i}=\frac{\beta_{1}}{\left(1+e^{\left(\beta_{2}-\beta_{3} x_{i}\right)}\right)}+e_{i}$ \\
\hline Gompertz & $\left.\left.y_{i}=\beta_{1} e^{\left(-e\left(\beta_{23} \beta x_{i}\right.\right.}\right)\right)+e_{i}$ \\
\hline Schnute & $y i=\frac{\beta_{1}}{\left(1+\beta_{4} e^{\left(\beta_{3} \beta_{2}-x_{i}\right)}\right) \frac{1}{\beta_{4}}}+e_{i}$ \\
\hline Mitscherlich & $y_{i}=\beta_{1}\left(1-e^{\left(\beta_{3} \beta_{2}-\beta_{3} x_{i}\right)}\right)+e_{i}$ \\
\hline Meloun I & $y_{i}=\beta_{1}-\beta_{2} e\left(-\beta_{3} x_{i}\right)+e_{i}$ \\
\hline Meloun II & $y_{i}=\beta_{1}\left(1-e^{\left(-x-\beta_{2}\right)} \beta_{3}\right)$ \\
\hline Meloun III & $y_{i}=\beta_{1}-e^{\left(-\beta_{2}-\beta_{3} x_{i}\right)}+e_{i}$ \\
\hline Gamito & $y_{i}=\frac{1}{\left(\beta_{1}+\beta_{2} \beta_{3}\right)}$ \\
\hline Meloun IV & $y_{i}=\beta_{1}-\beta_{2} e^{\left(-\beta_{3} x \beta_{4}\right)}$ \\
\hline
\end{tabular}

where:

$R^{2}=1-\frac{S Q R}{S Q T}$

$S Q R=\sum_{i=1}^{n}\left(Y_{i}-\hat{Y}_{i}\right)^{2}$ is the sum of squares of the residue;

$\hat{Y}_{i}=f\left(x_{i}, \hat{\theta}\right) ;$ and

$S Q T=\sum_{i=1}^{n}\left(Y_{i}-\bar{Y}\right)^{2}$ is the sum of total squares.

$\mathrm{N}$ stands for the number of observations used to adjust the curve and $p$ refers to the number of function parameters, including the intercept.

Akaike information criterion (AIC), which allows using the principle of parsimony to select the best model, i.e., the most parameterized model, is not necessarily the best one (Burnham, 2004). Lower AIC values reveal better adjustment (Akaike, 1974). This criterion is expressed by:

$$
\text { AIC }=-2 \log \text { like }+2 p
$$

where $\mathrm{p}$ denotes the number of parameters and loglike refers to the logarithmic value of the likelihood function as a function of the parameter estimates.

Bayesian information criterion (BIC): similarly to AIC, this evaluator takes the degree of the model into account. Therefore, the lower the BIC value (Schwartz, 1978), the better the model fitting. Its expression is described as follows:

$$
B I C=-2 \operatorname{loglike}+p 1 n(n)
$$

where $\mathrm{n}$ denotes the number of observations used to adjust the curve.

Mean square error of prediction (MEP) is an efficient criterion for testing the quality of a regression model (Chrobok, 2004), which is described as:

$$
M E P=\frac{\sum_{i-1}^{n}\left(y i-\hat{y} i^{*}\right)^{2}}{n}
$$

where $\hat{y}_{i}^{*}$ represents the estimated data, based on parameter values obtained from a fitting without observations; $i$ and $n$ refer to the number of observations.

Determination Coefficient of Prediction $\left(\mathrm{R}_{\mathrm{p}}^{2}\right)$ : this evaluator is equivalent to common $\mathrm{R}^{2}$, presenting the same interpretation; the difference is that the squared error and total sums are replaced, respectively, by the term nMEP and $\sum_{i=1}^{n} \hat{y}_{i}^{* 2}-n \bar{y}^{2}$, which includes the influence of the absence of every observation in model fitting. The formula is:

$$
\hat{R}^{2} p=1-\frac{n M E P}{\sum_{i=1}^{n} \hat{y} i^{* 2}-n \bar{y}^{2}}
$$

where $\bar{y}$ denotes the mean $\mathrm{n}$ values $\mathrm{y}_{\mathrm{i}}, \mathrm{I}=1,2, \ldots, \mathrm{n}$.

The analyzed parameters were obtained and adjusted for each animal. Thus, the values of assessors that composed 
the dataset used in multivariate analyses were obtained by the grouping means of values obtained from each animal.

The tested nonlinear models were fitted using maximum likelihood estimation, optimization algorithm of GaussNewton, and the MODEL procedure in SAS software (Statistical Analysis System - SAS, version 9.1). The initial parameters values were determined after several attempts, in order to identify values with a minimum number of iterations to convergence.

After verifying the convergence of models, a data file containing the identification of the model and mean values corresponding to each evaluator was drafted. These data were subjected to cluster analysis - CLUSTER procedure - using the centroid method (v. 9.1). In this method, the distance between two groups is determined by the Squared Euclidean Distance between the vector mean (centroid) of the two groups.

After selecting the best adjusted model(s), the influence of sex and type of birth (simple and double) on the curve parameters was evaluated using the GLM procedure of SAS (v. 9.1). Likewise, Pearson's correlation coefficients between parameters were estimated.

The absolute growth rate (AGR) obtained from the first derivation of the fitted model was calculated as a function of time $(\partial Y / \partial t)$. In fact, AGR denotes the weight gain per unit of time; thus, the time expressed in days represents the average daily weight gain estimated over growth, i.e., the average growth rate. In case of those models without an inflection point, the maximum geometric curvature method was adopted (Cecon et al., 2008) to determine the age at which animals had lower weight gains.

\section{Results and Discussion}

Schnute, Meloun II and Gamito models did not converge and, because of that, their parameters and graphs were not presented.

Parameter $\beta_{1}$ represents the asymptotic weight, which is interpreted as adult weight. Estimates of this parameter for Morada Nova sheep (Table 2), using Gompertz and Logistic models, were higher than those reported by Sarmento et al. (2006), involving Santa Ines sheep (24.2 and 23.2).

Parameter $\beta_{3}$ denotes animal maturity and indicates the growth rate to achieve the asymptotic weight. In this parameter, the estimates of Gompertz and Logistic models were lower than those obtained by Sarmento et al. (2006) using Gompertz $\left(\beta_{3}=0.019\right)$ and Logistic $\left(\beta_{3}=0.028\right)$ models. On the other hand, using Gompertz model, Malhado et al. (2009) reported 0.017, 0.015 and 0.013 for Dorper $\times$ Santa
Inês, Dorper $\times$ Morada Nova and Dorper $\times$ Rabo Largo hybrids, respectively.

All models showed determination coefficients of prediction $\left(\mathrm{R}_{\mathrm{p}}^{2}\right)$ higher than $99 \%$ (Table 3). Based on the adjusted coefficient of determination $\left(\mathrm{R}_{\mathrm{aj}}^{2}\right)$, the Mitscherlich, Meloun I, Meloun III and Meloun IV models yielded values above $91 \%$. However, the Mitscherlich model showed a higher value for MEP.

On the other hand, the adjustment of models Meloun I, Meloun III and Meloun IV were superior to others, showing lower AIC, BIC and MEP values. Yet, when analyzing the dendrogram and considering a cutoff point of about 0.25 (Figure 1), model Meloun III differs from both Meloun I and Meloun IV. Furthermore, the models Meloun I and Meloun IV showed lower BIC and MEP values in relation to Meloun III. Accordingly, models Meloun I and Meloun $\mathrm{IV}$ are equivalent to explain the growth of animals and were considered the best models (Figure 2).

Surprisingly, the use of Meloun I and Meloun IV to describe animal growth has not been reported in the literature. Chrobok et al. (2004) adopted these nonlinear models to describe the increase in the height of the stirrup bone in human fetuses. These authors stated that the models with the best fitting results represent the normal

Table 2 - Estimate of parameters $\beta_{1}$ (asymptotic weight), $\beta_{2}$ (integration constant) and $\beta_{3}$ (maturing rate) for growth models, considering the average fitting index

\begin{tabular}{lcrcc}
\hline \multirow{2}{*}{ Model } & \multicolumn{4}{c}{ Estimates } \\
\cline { 2 - 5 } & $\hat{\beta}_{1}$ & $\hat{\beta}_{2}$ & $\hat{\beta}_{3}$ & $\hat{\beta}_{3} \hat{\beta}_{4}$ \\
\hline Mitscherlich & 28.5665 & -24.5108 & 0.0066 & - \\
Gompertz & 26.8185 & 0.5944 & 0.0112 & - \\
Logistic & 25.1995 & 1.4001 & 0.0164 & - \\
Meloun I & 29.2368 & 25.9289 & 0.0063 & - \\
Meloun III & 28.9662 & -3.2043 & 0.0065 & - \\
Meloun IV & 29.4372 & 22.4265 & - & 0.0065 \\
\hline
\end{tabular}

Due to difficulties in convergence, we adopted reparametrization, wherein 0.0065 represents the product $\beta_{3} \beta_{4}$.

Table 3 - Estimates of Akaike Information Criterion (AIC), Bayesian Information Criterion (BIC), Adjusted Coefficient of Determination $\left(\mathrm{R}_{\mathrm{aj}}^{2}\right)$, Root Mean Square Error of Prediction (MEP) and Determination Coefficient of Prediction $\left(\mathrm{R}_{\mathrm{p}}^{2}\right)$, according to the studied models

\begin{tabular}{lrrccc}
\hline \multirow{2}{*}{ Models } & \multicolumn{5}{c}{ Mean values } \\
\cline { 2 - 6 } & \multicolumn{1}{c}{ AIC } & \multicolumn{1}{c}{ BIC } & $\mathrm{R}^{2}{ }_{\text {aj }}$ & MEP & $\mathrm{R}_{\mathrm{p}}^{2}$ \\
\hline Mitscherlich & 93.351 & 96.811 & 0.910 & 4.020 & 0.993 \\
Gompertz & 96.493 & 99.948 & 0.909 & 4.205 & 0.993 \\
Logistic & 100.141 & 103.596 & 0.898 & 4.753 & 0.992 \\
Meloun I & 91.524 & 94.981 & 0.911 & 3.333 & 0.994 \\
Meloun III & 85.986 & 95.436 & 0.913 & 3.906 & 0.993 \\
Meloun IV & 90.375 & 93.823 & 0.931 & 2.931 & 0.995 \\
\hline
\end{tabular}




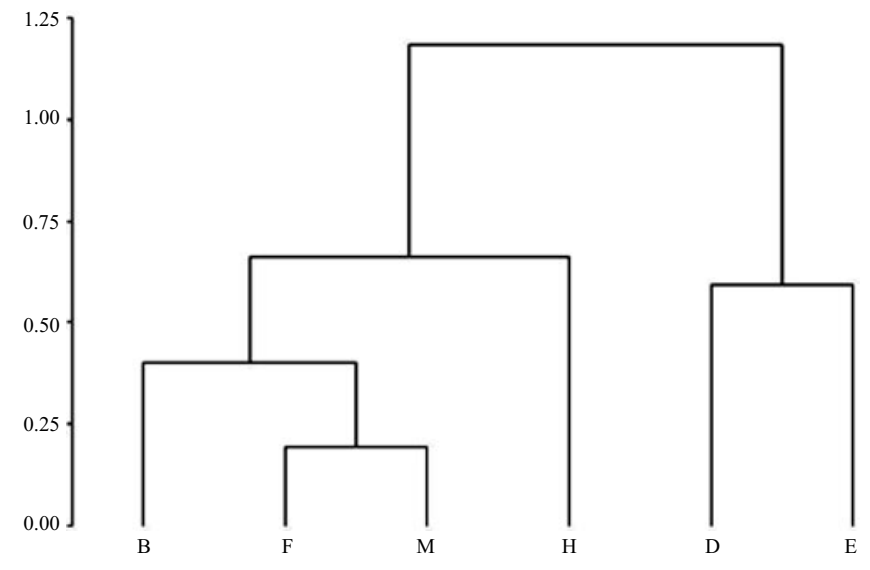

Figure 1 - Dendrogram of cluster analysis based on quality evaluators (AIC. BIC. $R^{2} a$. MEP and $R^{2} p$ ) for Mitscherlich (B) Gompertz (D) Logistic (E) Meloun I (F) Meloun III (H) and Meloun IV (M) models.

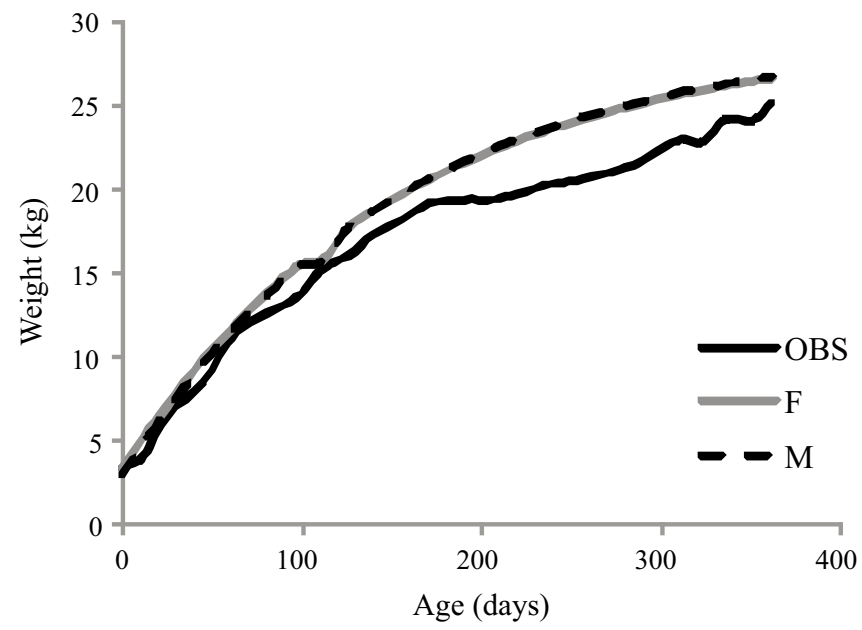

OBS - observed values.

Figure 2 - Estimate of weight as a function of age, adjusted for models Meloun I (F) and Meloun IV (M) in Morada Nova sheep.

development and, therefore, facilitate the detection of fetal malformations in humans.

Neither sex nor type of birth significantly influenced $(\mathrm{P}>0.05)$ the parameters of model Meloun I, corroborating studies by Malhado et al. (2008). These authors evaluated growth curves in Texel $\times$ Santa Inês crossbred sheep raised in the southwestern region of Bahia state and found that the sex had no effects $(\mathrm{P}>0.05)$ on parameters of the logistic function. Otherwise, Bathaei (1995), McManus et al. (2003) and Sarmento et al. (2006) showed that sex influenced the parameters of the logistic function.

Moreover, the correlation between estimates of parameters $\beta_{1}$ and $\beta_{3}$ was significant $(\mathrm{P}<0.05)$ and equal to -0.72 for the Meloun I model. The negative correlation between both parameters indicates that animals with lower growth rates reach higher weight at maturity. This is reinforced by the studies carried out by Malhado et al. (2008), Carneiro et al. (2007) and Lôbo et al. (2006), who reported negative correlations of $-0.87,-0.68$ and -0.44 for the Logistic, Logistic and Richards models, respectively.

Therefore, model Meloun I was chosen to describe the absolute growth rate (AGR) of the animals. The absolute growth rate was determined through the first derivative of the model, as a function of time (Figure 3a). As for
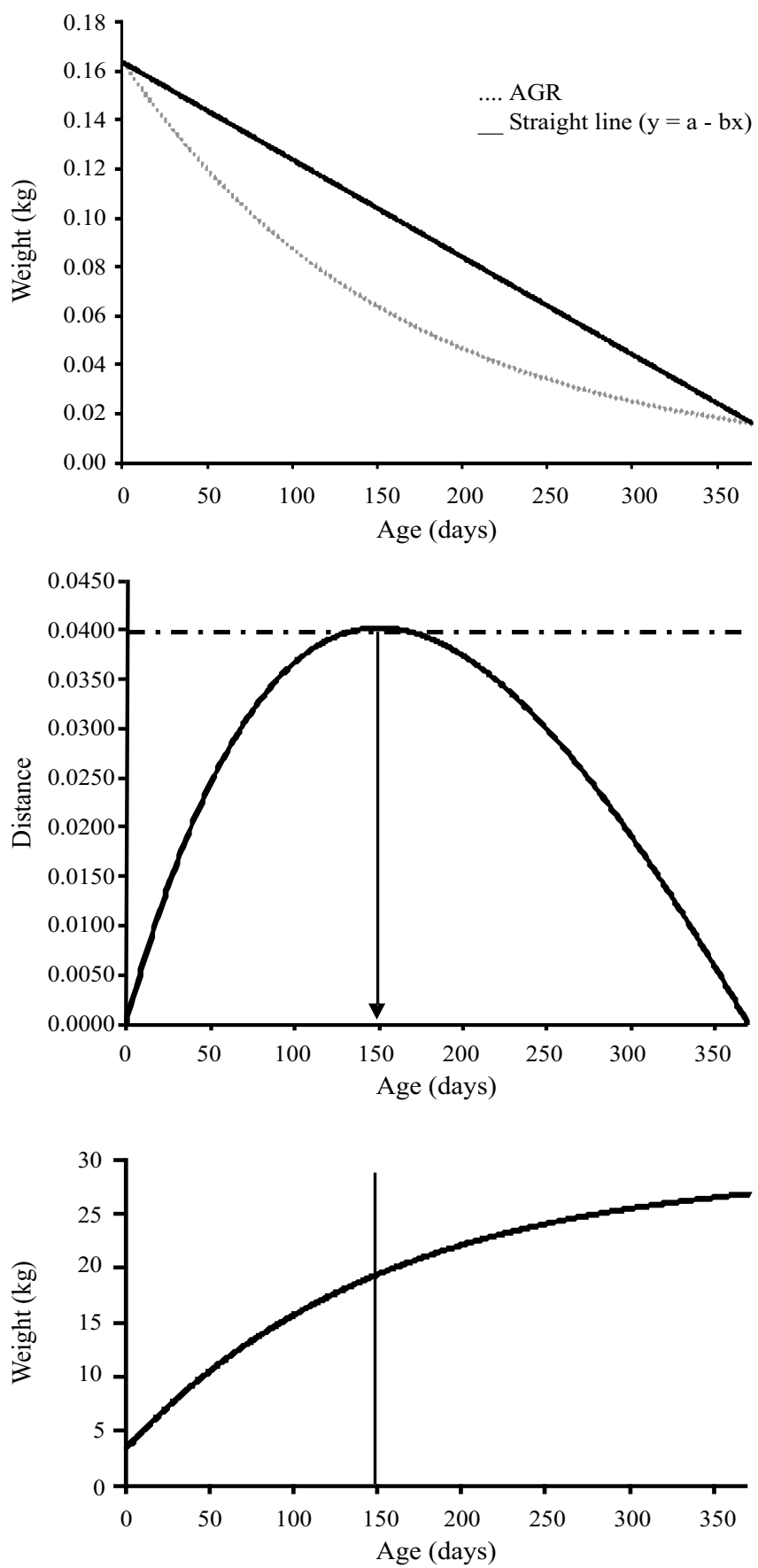

Figure 3 - Absolute growth rate (AGR) (a), point of maximum curvature (b) and weight estimate as a function of age using the Meloun I model (c). 
the models lacking an inflection point, the maximum geometric curvature method was adopted (Cecon et al., 2008) to determine the age at which animals had lower weight gain (Figure 3b). A reduction in weight gain was observed around 120 days of age, when lambs were weaned, with a peak after 150 days (Figure $3 \mathrm{c}$ ). In a previous study involving Santa Inês $\times$ Texel sheep, Malhado et al. (2008) also reported a steep decline of AGR after 150 days of age, corroborating the present results.

Thus, the adoption of an appropriate and specific nutritional management is essential to reduce the effects of diet change during weaning to avoid accentuated losses in AGR through the post-weaning period. This information is of strategic importance to assist producers and help determine the most economical age for slaughter, providing the best cost/benefit ratio.

\section{Conclusions}

The use of alternative nonlinear models coupled with new quality evaluators and cluster analysis is efficient to analyze the growth curves in Morada Nova sheep. The models Meloun I and IV have the best adjustment and reveal a remarkable reduction of weight gain after 150 days of age.

\section{References}

AKAIKE, H. A new look at the statistical model identification. IEEE transactions on Automatic Control, v.19, p.716-723, 1974.

BATHAEI, S.S. La croissance et le développement corporel de la naissance à la maturité dans la raça ovine iranienne Mehraban à queue grasse. Revue d'élevage et de Médicine Vétérinaire des Pays Troplcux, v.48, p.181-194, 1995.

BURNHAM, K.P.; ANDERSON, D.R. Multimodel inference: Understanding AIC and BIC in model selection. Sociological Methods Research, v.33, p.261, 2004.

CARNEIRO, P.L.S.; MALHADO, C.H.M.; SOUZA JÚNIOR, A.A.O. et al. Desenvolvimento ponderal e diversidade fenotípica entre cruzamentos de ovinos Dorper com raças locais. Pesquisa Agropecuária Brasileira, v.42, p.991-998, 2007.

CARNEIRO, P.L.S.; MALHADO, C.H.M.; AFFONSO, P.R.A.M. et al. Curva de crescimento em caprinos da raça Mambrina criados na caatinga. Revista Brasileira de Saúde Produção Animal, v.10, p.536-545, 2009.

CECON, P.R.; SILVA, F.F.; FERREIRA, A. et al. Análise de medidas repetidas na avaliação de clones de café 'Conilon'. Pesquisa Agropecuária Brasileira, v.43. p.1171-1176, 2008.

CHROBOK, V.; MELOUN, M.; SIMÁKOVÁ, E. Descriptive growth model of the height of stapes in the fetus: a histopathological study of the temporal boné. Eur Arch Otorhinolaryngol, v.261, p.25-29, 2004.

DOMINGUES, O. Carneiro deslanado de Morada Nova. Boletim da Sociedade Brasileira de Agronomia, v.4, n.1, p.122, 1941.

DOMINGUES, O. Os carneiros deslanados de Morada Nova. Revista de Agronomia, v.9, n.3, p.257-259, 1950.

FACÓ, O.; PAIVA, S.R.; ALVES, L.R.N. et al. Raça Morada Nova: origem, características e perspectivas. Sobral: Embrapa Caprinos, 2008. 43p. (Embrapa Caprinos. Documentos, 75).

FREITAS, A.R. Curvas de crescimento na produção animal. Revista Brasileira de Zootecnia, v.34, p.786-795, 2005.

GURGEL, M.A.; SOUZA, A.A.; LIMA, F.A.M. Avaliação do feno de leucena no crescimento de cordeiros Morada Nova em confinamento. Pesquisa Agropecuária Brasileira, v.27, p.1519-1526, 1992.

LÔBO, R.N.B.; VILLELA, L.C.V.; LÔBO, A.M.B.O. et al. Parâmetros genéticos de características estimadas da curva de crescimento de ovinos da raça Santa Inês. Revista Brasileira de Zootecnia, v.35, p.1012-1019, 2006.

MALHADO, C.H.M.; CARNEIRO, P.L.S.; MELLO, P.R.A.M. et al. Growth curves in Dorper sheep crossed with the local Brazilian breeds. Morada Nova. Rabo Largo. and Santa Inês. Small Ruminant Research, v.84, p.16-21, 2009.

MALHADO, C.H.M.; CARNEIRO, P.L.S.; SANTOS, P.F. et al. Curva de crescimento em ovinos mestiços Santa Inês x Texel criados no Sudoeste do Estado da Bahia. Revista Brasileira de Saúde e Produção Animal, v.9, p.210-218, 2008.

MELOUN, M.; MILITKY, J. Sbírka úloh. Statistické zpracování experimentálnich dat. Pardubice: Universita Pardubice, 1996. 308p.

McMANUS, C.; EVANGELISTA, C.; FERNANDES, L.A.C. et al. Curvas de crescimento de ovinos Bergamácia criados no Distrito Federal. Revista Brasileira de Zootecnia, v.32, p.1207-1212, 2003.

SARMENTO, J.L.R.; REZAZZI, A.J.; SOUZA, W.H. et al. Estudo da curva de crescimento de ovinos Santa Inês. Revista Brasileira de Zootecnia, v.35, p.435-442, 2006.

SCHWARZ, G. Estimating the dimension of a model. Annals of Statistics, v.6, p.461-464, 1978.

SILVA, N.A.M.; AQUINO, L.H.; SILVA, F.F. et al. Curvas de crescimento e influência de fatores não-genéticos sobre as taxas de crescimento de bovinos da raça Nelore. Ciência e Agrotecnologia, v.28, p.647-654, 2004.

SILVEIRA, F.G.; SILVA, F.F.; CARNEIRO, P.L.S et al. Análise de agrupamento na seleção de modelos de regressão não-lineares para curvas de crescimento de ovinos cruzados. Ciência Rural, v.41, p.692-698, 2011. 